\title{
Mating system parameters of Dryobalanops aromatica Gaertn. f. (Dipterocarpaceae) in three different forest types and a seed orchard
}

\author{
S. L. LEE* \\ Forest Research Institute Malaysia (FRIM), Kepong, 52109 Kuala Lumpur, Malaysia
}

\begin{abstract}
The mating system of Dryobalanops aromatica in three different forest types and a seed orchard was quantified by allozyme analysis of progeny arrays using a mixed-mating model. The primary forest (Bukit Sai) had the highest multilocus outcrossing rate $\left(t_{\mathrm{m}}=0.923 \pm 0.035\right)$, followed by logged forest (Lesong; $t_{\mathrm{m}}=0.766 \pm 0.056$ ) and artificial forest (FRIM; $t_{\mathrm{m}}=0.661 \pm 0.066$ ) with seed orchard showing the lowest (Tampin; $t_{\mathrm{m}}=0.551 \pm 0.095$ ). Deviations from the mixed mating model were evident from differences in pollen and ovule allele frequencies, and heterogeneity of pollen pools in all three different forest types and the seed orchard. A high rate of outcrossing in primary forest $\left(t_{\mathrm{m}}=0.92\right)$ may indicate that the species is self-incompatible, but a lower value in the seed orchard $\left(t_{\mathrm{m}}=0.55\right)$ might suggest further that the self-incompatibility system is weak. The outcrossing rate was greater in the primary forest $\left(t_{\mathrm{m}}=0.92\right)$ than in logged forest $\left(t_{\mathrm{m}}=0.77\right)$. It is argued that this might be a consequence of the lower density of flowering trees and alteration of pollinator foraging behaviour in logged forest. Higher values of correlated mating $\left(r_{\mathrm{p}}\right)$ and biparental mating $\left(t_{\mathrm{m}}-t_{\mathrm{s}}\right)$ in primary forest $(0.08$ and 0.39 , respectively) in comparison with logged forest $(0.03$ and 0.11 , respectively) demonstrate that logging activities might reduce the seeds produced through consanguineous mating. Compared with primary forest, it is argued that lower rates of outcrossing in artificial forest $\left(t_{\mathrm{m}}=0.67\right)$ and seed orchard $\left(t_{\mathrm{m}}=0.55\right)$ might be attributed to lack of flowering synchrony and insufficient number of pollinators. The high level of correlated mating $\left(r_{\mathrm{p}}=0.43\right)$ and biparental mating $\left(t_{\mathrm{m}}-t_{\mathrm{s}}=0.12\right)$ in the seed orchard may further suggest that the seed orchard was established using related seed sources.
\end{abstract}

Keywords: allozyme, Dipterocarpaceae, Dryobalanops aromatica, Kapur, mating system, tropical rain forest.

\section{Introduction}

The mating system is an important determinant of the genetic structure and evolutionary inherent of natural populations because it establishes the pattern of how uniting gametes form the next generation (Allard, 1975). It is dynamic and can vary in space and time. Heterogeneity of outcrossing rates has been observed among populations (Liengsiri et al., 1998), among individuals within a population and between fruiting seasons (Murawski et al., 1994a). It can be a result of ecological factors, such as size and density of populations, density of flowering trees, flower phenology, pollinator foraging

*Correspondence. E-mail: leesl@frim.gov.my behaviour and relative number of pollinators (Brown et al., 1989; Adams, 1992; Mitton, 1992).

The destruction of tropical forest by logging activities may have many diverse effects on the forest biodiversity. These include the changes of competitors among plant species, alteration in pollen and seeds dispersal patterns via animal vectors, and contraction in effective population sizes of plants and animals (Nason et al., 1997). As most tropical trees are animal pollinated (Bawa et al., 1985; Bawa, 1990), changes in plant density and the destruction of pollinator habitats may have critical effects on the fertilization success of individual trees within a fragmented landscape (Aizen \& Feinsinger, 1995).

Dryobalanops aromatica, locally known as Kapur, is an emergent canopy tree occurring in Sumatra, Riau 
Archipelaga, Borneo and Peninsular Malaysia (Symington, 1943). It occurs abundantly in the lowlands but also occurs in the hills (up to $365 \mathrm{~m}$ altitude). In Peninsular Malaysia, it is limited to the eastern coast of Trengganu, Pahang and Johor, as long belts just inside the beach area. In Johor, it spreads westwards into the hills (Wyatt-Smith, 1964). In gregarious stands, it may make up to $90 \%$ of the total volume of timber (Foxworthy, 1927). The tree is easily distinguished by its purple brown, scaly bark, its aromatic cut and small, aromatic, ovate leaves. It flowers simultaneously and has small white hermaphrodite flowers. In Peninsular Malaysia, the reported floral visitors are honey bees, Apis dorsata and $A$. indica var. cerrana (Appanah, 1981; Ashton, 1988). The fruits have an ovate nut, large wing (about $5 \mathrm{~cm}$ long) and are dispersed by gravity; thus most of the fruits fall under the crown of the mother tree. It is one of the fastest growing timber species in Peninsular Malaysia. The timber is a medium hardwood and is moderately durable in tropical conditions. It is suitable for heavy construction, posts, beams, joints and railway sleepers.

Estimations of outcrossing rates in plant populations have been reported for several tropical species and most of the species are predominantly outcrossing (summarized by Nason \& Hamrick, 1997). Recent studies have focused on how the outcrossing rates can be influenced by forest activities. Murawski et al. (1994b) found that the reduction in population density of Shorea megistophylla following a selective logging event had enhanced selfing substantially. Similarly, Murawski \& Hamrick (1992a) reported that the outcrossing rates of Cavanillesia platanifolia were positively correlated with density of flowering trees. However, Hall et al. (1996) demonstrated outcrossing rates to be independent of tree density in Pithecellobium elegans. The low density of flowering adults just resulted in poor seed crops or failure to set fruit for many individuals. Doligez \& Joly (1997) reported that in Carapa procera, outcrossing rates in logged plots were significantly lower than in undisturbed plots, even though tree density in logged plots was not significantly different from undisturbed plots. In contrast, Kitamura et al. (1994) found no significant difference for outcrossing rates of $D$. aromatica from Brunei in secondary $\left(t_{\mathrm{m}}=0.79\right)$ and primary forest stands $\left(t_{\mathrm{m}}=0.86\right)$, even though flowering tree density in secondary forest was significantly lower than primary forest. Comparing outcrossing in artificial and natural forests is fundamental to a better understanding of mating systems in artificial populations and provides useful information for seed orchard design and management. Besides looking at natural populations (primary forest and logged forest), this study also investigated the mating characteristics of $D$. aromatica in an artificial forest and a seed orchard, established outside the native range of the species. No information on $D$. aromatica mating system parameters from artificial forest and seed orchards is currently available. It is postulated that in artificial forest and seed orchards, effective breeding population sizes are reduced due to lack of flowering synchrony.

\section{Materials and methods}

The three different forest types and a seed orchard were located in Peninsular Malaysia. Bukit Sai (Compartment $8 \mathrm{~b}$ ) was the primary forest, Lesong (compartment 129) the logged forest, Forest Research Institute Malaysia (FRIM; field 25, 9/11 and 10v) the artificial forest, and Tampin the seed orchard. Bukit Sai and Lesong belong to the lowland dipterocarp forest types with $D$. aromatica being the predominant species. Selective logging operations in Lesong carried out between 1996 and 1997 intensively reduced the density of mature $D$. aromatica and other dipterocarp trees. The artificial forest of FRIM was established in 1927; its 200 ha comprises $D$. aromatica and various dipterocarp and nondipterocarp timber tree species, and is surrounded by primary and secondary forests. The $D$. aromatica seed orchard of Tampin ( 2 ha) was established in 1928 by the Forest Department and is surrounded by rubber plantations. The seed source of the artificial forest and seed orchard is unknown.

Estimations of the densities of $D$. aromatica mature trees (more than $30 \mathrm{~cm}$ d.b.h.) were made from five plots, each 0.25 ha in area, in each of the three forest types and the seed orchard. Fifteen individuals per hectare were found in Bukit Sai, seven in Lesong, 16 in FRIM and 20 in Tampin. During August 1998, the mass fruiting season of $D$. aromatica in Peninsular Malaysia, estimates based on the five plots showed that approximately $60 \%$ of the adult trees in Bukit Sai and Lesong, $40 \%$ in FRIM and $30 \%$ in Tampin were fruiting. Ten mother trees were selected each from Bukit Sai, Lesong and Tampin and 15 from FRIM. Mother trees were selected randomly with intervening distances of 100-1000 m. Seeds were collected using the 'shakingcatch' method, in which a weight attached to a nylon fishing string was shot over a branch using a catapult, and used to haul up a thicker, stronger nylon line. The ends of the line were then pulled vigorously to detach the seeds; the seeds were easily caught as they gyrated toward the ground (Lee et al. 2000a).

Embryos of 35-40 seeds of each mother tree were homogenized in $200 \mu \mathrm{L}$ extraction buffer, consisting of $50 \mathrm{~mm}$ borate buffer ( $\mathrm{pH} 8.0$ ), 1\% PVP-40, 2\% BSA, $10 \mathrm{~mm}$ ascorbic acid, $6 \mathrm{~mm}$ DTT, $20 \mathrm{~mm} \mathrm{Na}_{2} \mathrm{~S}_{2} \mathrm{O}_{5}$, $0.1 \% \quad \beta$-mercaptoethanol, $\quad 0.05 \mathrm{M} \quad$ DIECA, $\quad 0.5 \mathrm{M}$ 
sucrose, $1 \%$ tween-80, 1\% 20 м PEG, $0.5 \%$ 2-phenoxyethanol, $1 \%$ tergitol, $0.2 \% \mathrm{MgCl}_{2}, 0.2 \% \mathrm{CaCl}_{2}$ and $5 \mathrm{~mm}$ EDTA. Electrophoresis was performed using horizontal starch gel. Genetic interpretations of the banding patterns were based on two criteria: (i) if the maternal genotype for a given locus was heterozygous, approximately half of the progeny were heterozygous, consistent with expectations of selfing, outcrossing, or mixed mating; and (ii) all progenies carried at least one maternal allele. Nine allozyme systems were selected for consistent resolution and enzymatic activity. Malate dehydrogenase (MDH), isocitrate dehydrogenase (IDH), phosphogluconate dehydrogenase (PGD) and hexokinase (HEK) staining zones appeared polymorphic but were uninterpretable, and were omitted for the analysis. Alcohol dehydrogenase (ADH) was monomorphic. The remaining allozyme systems were assayed on two gel and electrode buffer systems. Aspartate aminotransferase (AAT) was resolved on a lithium borate buffer (Ashton \& Braden, 1961); glucose phosphate isomerase (GPI), phosphoglucomutase (PGM), and shikimic dehydrogenase (SDH) were resolved on a morpholine citrate buffer system at $\mathrm{pH} 6.1$ (Clayton \& Tretiak, 1972). For enzyme systems with either more than one zone of activity or in zones of activity with more than one allozyme, the zones/loci were designated numerically (beginning with 1) and alleles were designated alphabetically (beginning with $A$ ), both in decreasing order of relative mobility.

Mating system parameters were determined using the estimation procedures of Ritland (1994), based on the mixed mating model of Brown \& Allard (1970). From progeny array data and through maximum likelihood procedures, the program simultaneously estimated: multilocus outcrossing rate $\left(t_{\mathrm{m}}\right)$ using the Newton Raphson method; average single locus outcrossing rate $\left(t_{\mathrm{s}}\right)$; pollen and ovule allele frequencies ( $p$ and $o$ ) using the expectation maximization method; correlation of outcrossed paternity within progeny arrays or probability that a randomly chosen pair of progeny from the same array are full sibs $\left(r_{\mathrm{p}}\right)$ using the Newton Raphson method; and variances of the above quantities using the bootstrap method where the progeny array (within families) is the unit of resampling (250 bootstrap replicates). Maternal genotypes were derived following the method of Brown \& Allard (1970).

The assumptions of the multilocus mixed mating model are that: (i) each mating event represents a random outcross or a self-fertilization; (ii) segregation within locus is assumed not to be linked to other loci; (iii) no postmating selection occurs; (iv) segregation in the heterozygous maternal trees is assumed to be strictly Mendelian in 1:1 ratio for both pollen and ovule production; (v) outcrossing rates are uniform across maternal genotypes; and (vi) the pollen pool is assumed to be homogeneous over all the maternal trees (Ritland \& Jain, 1981; Brown et al., 1989). In order to test for violations of the last assumption of the mixed mating model, chi-squared tests were performed to determine homogeneity of the pollen pool reaching each female. The calculation of the test statistic was performed as $\chi^{2}=N G_{\mathrm{ST}}(A-1)$, where $N$ is the total number of pollen gametes, $G_{\mathrm{ST}}$ is the proportion of among-tree variance in pollen allele frequencies relative to the total variance in pollen allele frequencies and $A$ is the number of alleles at a locus (James et al., 1998). The degrees of freedom are $(M-1)$, where $M$ is the number of maternal tree examined. Differences between pollen and ovule frequencies were tested by $\chi^{2}=K F_{\mathrm{ST}}(A-1)$ which has $(A-1)$ degrees of freedom. $K$ is the sum of the number of pollen and ovule gametes and $F_{\mathrm{ST}}$ is the genetic diversity between pollen and ovule pools (Murawski \& Hamrick, 1992b).

\section{Results}

Multilocus and single locus outcrossing rates estimated in the three forest types and the seed orchard are shown in Table 1. The primary forest (Bukit Sai) had the highest multilocus outcrossing rate $\left(t_{\mathrm{m}}=0.923 \pm 0.035\right), \quad$ followed by logged forest (Lesong; $t_{\mathrm{m}}=0.766 \pm 0.056$ ) and artificial forest (FRIM; $t_{\mathrm{m}}=0.661 \pm 0.066$ ), with seed orchard showing the lowest (Tampin; $t_{\mathrm{m}}=0.551 \pm 0.095$ ). Average single locus estimates of outcrossing value $\left(t_{\mathrm{s}}\right)$ were consistently lower than multilocus estimates in all the three forest types and the seed orchard, ranging from 0.843 (Bukit Sai) to 0.436 (Tampin). Interlocus variation of single locus outcrossing rate is evident in all except Lesong (Table 1). As all estimates were made from the same set of embryos, variability in the actual proportions of selfed and outcrossed progenies might not be conferred to the observed single locus estimates of outcrossing rate. The variability is likely a consequence of random variation and violation of the assumptions inherent to the estimation procedure, for example the heterogeneous pollen pool or positive assortative mating.

Inference of biparental mating can be made from the comparison between multilocus and average single locus outcrossing rates. Single locus outcrossing rate is expected to be biased downward by any inbreeding in addition to selfing, thus the mean is expected to be lower than the multilocus outcrossing rate when mating among relatives occurs (Brown, 1989). Comparison of these two values in Table 1 showed that Tampin has the highest value of biparental mating $\left(t_{\mathrm{m}}-t_{\mathrm{s}}=\right.$ $0.115 \pm 0.022$ ) and Lesong exhibited the lowest 
Table 1 Mating system parameters of $D$. aromatica in three different forest types and a seed orchard, where $t_{\mathrm{m}}$ represents the multilocus outcrossing rate, $t_{\mathrm{s}}$ is the single locus outcrossing rate. The index of correlated mating $\left(r_{\mathrm{p}}\right)$ measures the probability of a randomly chosen pair of progeny from the same array comprise full sibs. Standard deviations are in parentheses

\begin{tabular}{|c|c|c|c|c|c|}
\hline Forest type & $t_{\mathrm{m}}$ & & $t_{\mathrm{s}}$ & $t_{\mathrm{m}-} t_{\mathrm{s}}$ & $r_{\mathrm{p}}$ \\
\hline $\begin{array}{l}\text { Bukit Sai } \\
\text { (Primary forest) }\end{array}$ & $0.923(0.035)$ & $\begin{array}{l}\text { Mean } \\
\text { Aat } \\
\text { Gpi-2 } \\
\text { Pgm } \\
\text { Sdh-1 } \\
\text { Sdh-2 }\end{array}$ & $\begin{array}{l}0.843(0.027) \\
0.701(0.082) \\
0.921(0.134) \\
0.773(0.223) \\
0.812(0.251) \\
1.000(0.159)\end{array}$ & $0.080(0.026)$ & $0.389(0.076)$ \\
\hline $\begin{array}{l}\text { Lesong } \\
\text { (Logged forest) }\end{array}$ & $0.766(0.056)$ & $\begin{array}{l}\text { Mean } \\
\text { Aat } \\
\text { Gpi-2 } \\
P g m \\
\text { Sdh-1 } \\
\text { Sdh-2 }\end{array}$ & $\begin{array}{l}0.730(0.055) \\
0.725(0.070) \\
0.710(0.039) \\
0.754(0.193) \\
0.760(0.213) \\
0.706(0.287)\end{array}$ & $0.036(0.014)$ & $0.107(0.063)$ \\
\hline $\begin{array}{l}\text { FRIM } \\
\text { (Artificial forest) }\end{array}$ & $0.661(0.066)$ & $\begin{array}{l}\text { Mean } \\
\text { Aat } \\
\text { Gpi-2 } \\
\text { Pgm } \\
\text { Sdh-1 } \\
\text { Sdh-2 }\end{array}$ & $\begin{array}{l}0.611(0.016) \\
0.505(0.085) \\
0.667(0.085) \\
0.701(0.095) \\
0.718(0.136) \\
0.518(0.071)\end{array}$ & $0.051(0.016)$ & $0.378(0.083)$ \\
\hline $\begin{array}{l}\text { Tampin } \\
\text { (Seed orchard) }\end{array}$ & $0.551(0.095)$ & $\begin{array}{l}\text { Mean } \\
\text { Aat } \\
\text { Gpi-2 } \\
\text { Pgm } \\
\text { Sdh-1 } \\
\text { Sdh-2 }\end{array}$ & $\begin{array}{c}0.436(0.112) \\
0.368(0.136) \\
0.452(0.113) \\
0.507(0.127) \\
0.089(0.023) \\
-\end{array}$ & $0.115(0.022)$ & $0.428(0.093)$ \\
\hline
\end{tabular}

$(0.036 \pm 0.014)$. Similarly, the probability that progeny from the same array are full sibs, was highest within the maternal trees in Tampin $\left(r_{\mathrm{p}}=0.428 \pm 0.093\right)$ and lowest within the mother trees in Lesong $\left(r_{\mathrm{p}}=0.107 \pm 0.063\right)$.

Significant differences in pollen and ovule allele frequencies were detected in all the loci for each of the three forest types and the seed orchard $(P<0.01$; Table 2). These observed discrepancies in allele frequencies between the pollen and ovule pools may have been caused by migration of pollen from outside the population in the natural forest (primary and logged) and nonrandom mating of genotypes during outcrossing events in artificial forest and seed orchard. It might also be a consequence of the small number of maternal parents sampled from each population; estimates of allele frequencies of ovule are likely to differ significantly by chance from ovule allele frequencies in the total adult population.

Violation of the mixed mating model occurs when significant heterogeneity in pollen allele frequencies exists among maternal trees. As shown in Table 3, the null hypotheses of homogeneity of pollen pool gene frequencies over maternal parent was rejected for all the loci (except $S d h-1)$ in each of the three forest types and the seed orchard $(P<0.01)$, indicating that the maternal tree did not receive pollen at random from all synchronously flowering trees. The consequence of this violation is not readily measurable, but as shown by Ritland \& Jain (1981), it has a minor effect on the multilocus estimates of the population outcrossing rates.

\section{Discussion}

The multilocus outcrossing rate $\left(t_{\mathrm{m}}\right)$ from primary forest was 0.92 , indicated that $D$. aromatica under natural conditions can be grouped under the predominantly outcrossing category. This value is slightly higher than reported for the same species in Brunei $\left(t_{\mathrm{m}}=0.86\right)$, and some of the dipterocarp species such as Shorea congestiflora $\left(t_{\mathrm{m}}=0.87\right.$; Murawski et al., 1994a), S. megistophylla $\left(t_{\mathrm{m}}=0.81\right.$; Murawski et al., 1994b), S. leprosula $\left(t_{\mathrm{m}}=0.84 ;\right.$ Lee et al., 2000b) and Stemonoporus oblongifolius $\left(t_{\mathrm{m}}=0.84\right.$; Murawski \& Bawa, 1994). 
Table 2 Pollen and ovule allele frequencies (only two most common alleles are shown) and significance for $\chi^{2}$-tests of homogeneity between pollen and ovule pools of $D$. aromatica in three different forest types and a seed orchard. $G_{\mathrm{ST}}$ is the genetic heterogeneity between pollen and ovule allele frequencies

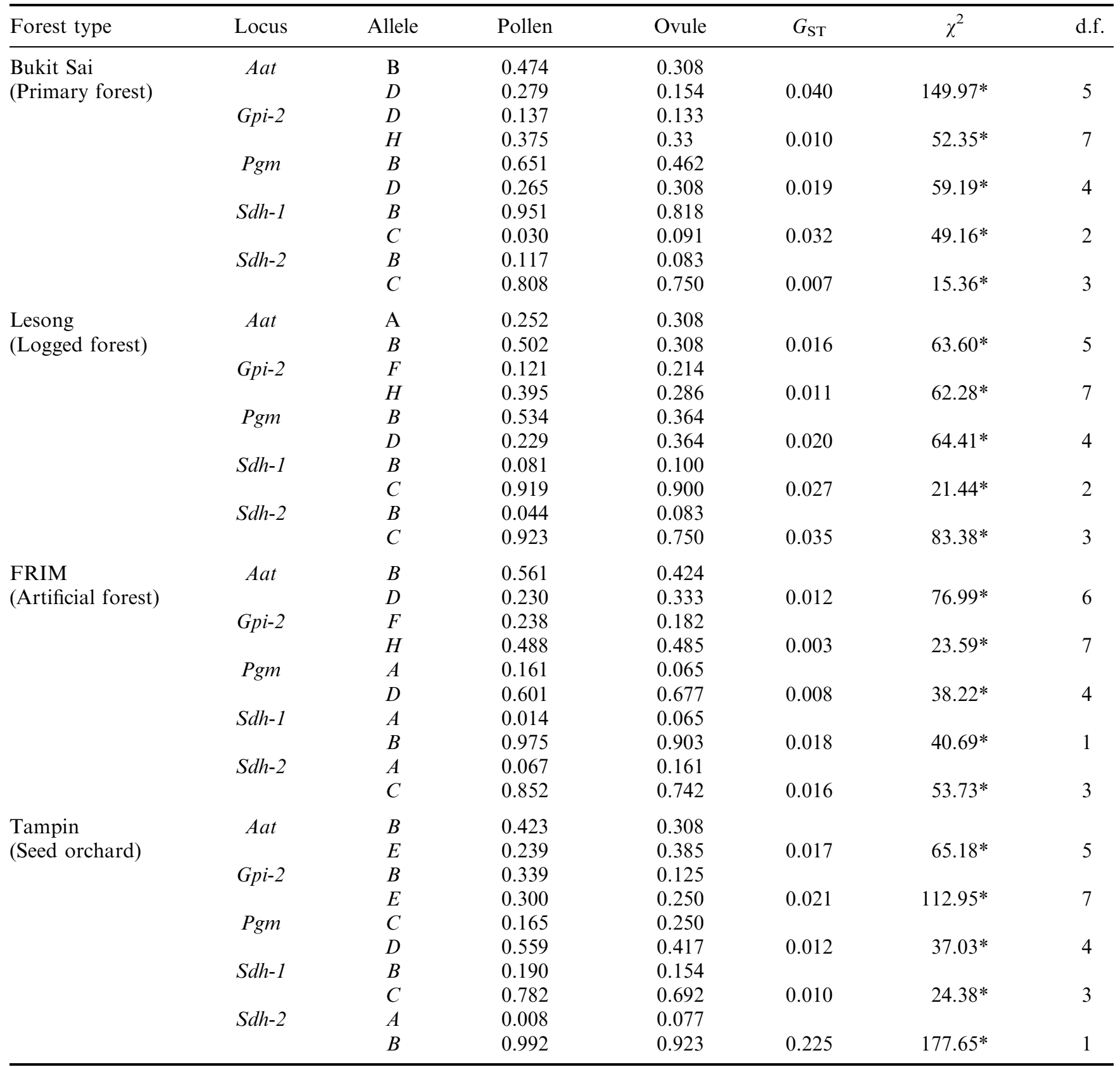

* Indicates significance at $P<0.01$.

Controlled pollinations have revealed the presence of self-incompatibility systems in a large number of dipterocarp species (Chan, 1981; Dayanandan et al., 1990; Sakai et al., 1999). Even though controlled pollinations have not been carried out for D. aromatica, high rates of outcrossing observed in natural forest, and the hermaphrodite nature of their flowers, indicate that self-incompatibility is present. However, low rates of outcrossing observed in the seed orchard $\left(t_{\mathrm{m}}=0.55\right)$ may also indicate that the self-incompatibility system is apparently weak, as a large proportion of seeds were produced through selfing.

Kitamura et al. (1994) who worked on D. aromatica in Brunei demonstrated that the outcrossing rate of logged forest was not significantly different from primary forest. However, in this study, outcrossing rate 
Table 3 Summary of the pollen allele frequency diversity among maternal trees $\left(G_{\mathrm{ST}}\right)$ of $D$. aromatica in three different forest types and a seed orchard. $\chi^{2}$-test to assess homogeneity of the pollen reaching each maternal tree

\begin{tabular}{lcccc}
\hline Forest type & Locus & $G_{\mathrm{ST}}$ & $\chi^{2}$ & d.f. \\
\hline Bukit Sai & Aat & 0.124 & $231.67^{*}$ & 9 \\
(Primary forest) & $G p i-2$ & 0.090 & $238.26^{*}$ & 9 \\
& $P g m$ & 0.038 & $59.64^{*}$ & 9 \\
& Sdh-1 & 0.015 & $11.72^{\mathrm{NS}}$ & 9 \\
& Sdh-2 & 0.095 & $110.50^{*}$ & 9 \\
Lesong & Aat & 0.051 & $101.22^{*}$ & 9 \\
(Logged forest) & Gpi-2 & 0.046 & $127.97^{*}$ & 9 \\
& $P g m$ & 0.084 & $133.36^{*}$ & 9 \\
& Sdh-1 & 0.049 & $19.25^{\mathrm{NS}}$ & 9 \\
& Sdh-2 & 0.022 & $25.98^{*}$ & 9 \\
FRIM & Aat & 0.128 & $448.79^{*}$ & 14 \\
(Artificial forest) & $G p i-2$ & 0.098 & $388.83^{*}$ & 14 \\
& $P g m$ & 0.108 & $245.38^{*}$ & 14 \\
& Sdh-1 & 0.010 & $11.51^{\mathrm{NS}}$ & 14 \\
& Sdh-2 & 0.112 & $192.28^{*}$ & 14 \\
Tampin & Aat & 0.158 & $308.99^{*}$ & 9 \\
(Seed orchard) & $G p i-2$ & 0.142 & $387.24^{*}$ & 9 \\
& $P g m$ & 0.146 & $220.33^{*}$ & 9 \\
& Sdh-1 & 0.000 & $0.00^{\mathrm{NS}}$ & 9 \\
& $S d h-2$ & 0.331 & $392.44^{*}$ & 9 \\
\hline
\end{tabular}

* significance at $P<0.01 ;$ NS, not significant.

was clearly greater in primary forest $\left(t_{\mathrm{m}}=0.92\right)$ than in logged forest $\left(t_{\mathrm{m}}=0.77\right)$. Reductions of outcrossing rate in logged forests than in primary forests have been documented for several tropical tree species (Shorea megistophylla: Murawski et al., 1994b; Pithecellobium elegans: Hall et al., 1996; Carapa procera: Doligez \& Joly, 1997). For this study, as the logged and primary forests are not interspersed within a single study site, it is possible that these differences in estimates result from plot-level factors rather than logging itself. However, as selective logging involves extracting a proportion of trees of reproductive size and, furthermore, as $D$. aromatica is the main targeted species for timber, local population density and density of flowering trees have been necessarily reduced. Estimations based on five 0.25 ha plots support this, with density of mature trees in logged forest $\left(7 \mathrm{ha}^{-1}\right)$ much lower than that in primary forest $\left(15 \mathrm{ha}^{-1}\right)$. Reduced numbers of flowering individuals in logged forest may result in changes of pollen quantity and quality, which, in turn, could lower pollinator densities (Bawa, 1990). Aided by a weak selfincompatibility system, this may significantly elevate the proportion of seeds produced through selfing.

As pollination results from a complex series of interactions between the plant and vector agent, condi- tioned by the environment experienced prior to and during anthesis, decrease in density is probably not the sole cause of the decrease in outcrossing rate on logged forest. As reviewed by Sedgley \& Griffin (1989), pollinator foraging behaviour can be affected by ambient conditions, wind speed, solar radiation and humidity; pollinator activities will be maximized if plots are located at sheltered sites where the weather is mild and sunny during the flowering period. Opening of the canopy due to logging would certainly increase local temperature and the amount of light penetration. It is argued that these local microclimatic changes might be unfavourable to pollinator movement and thus reduce the efficiency of intertree pollination. Besides, selective removal of trees might increase the local-scale distance among conspecifics, to such an extent that it could not be bridged by means of pollen flow. This may result in low levels of outcrossing. Higher values of correlated mating $\left(r_{\mathrm{p}}\right)$ and biparental mating $\left(t_{\mathrm{m}}-t_{\mathrm{s}}\right)$ in primary forest ( 0.080 and 0.389 , respectively) in comparison with logged forest ( 0.036 and 0.107 , respectively), may also suggest that the population is structured to some extent. With neighbours more closely related to each other than individuals farther away, thinning of the stand as a result of logging may reduce inbreeding by consanguineous mating.

The outcrossing rates of artificial forest $\left(t_{\mathrm{m}}=0.66\right)$ and seed orchards $\left(t_{\mathrm{m}}=0.55\right)$ are generally lower than primary forest $\left(t_{\mathrm{m}}=0.92\right)$. In contrast, a few studies on wind-pollinated species have reported outcrossing estimates from seed orchards to be higher than from natural populations (Shaw \& Allard, 1982; Rudin et al., 1986; Zheng \& Ennos, 1997). Comparisons of wind-and animal-pollinated species have shown that the outcrossing rates of wind-pollinated species are relatively insensitive to short-range environmental fluctuations, but influenced primarily by floral structure and degree of self-compatibility (Brown et al., 1989). As adult tree densities in FRIM and Tampin (16 and $20 \mathrm{ha}^{-1}$, respectively) are slightly higher than in primary forest $\left(15 \mathrm{ha}^{-1}\right)$, adult densities do not seem to account for the differences in outcrossing estimates. FRIM and Tampin are situated in the western part of Peninsular Malaysia, whereas the natural habitat of D. aromatica in Peninsular Malaysia is limited to the eastern coast of Terengganu, Pahang and Johor. This also means that during the cultivation processes, the plant is removed from the ecosystem in which its breeding system has evolved. Availability of pollinators in the new ecosystem might be one of the major factors that can reduce outcrossing events. Besides this, differences in climatic and weather conditions in the new ecosystem may effect the timing of floral development, resulting in lack of flowering synchrony, which can reduce the effective 
breeding population size. As shown in this study, during the August 1998 mass fruiting season of D. aromatica in Peninsular Malaysia, $60 \%$ of the adult trees in natural forest (primary and logged) flowered, in comparison with only $40 \%$ and $30 \%$ in artificial forest and seed orchard, respectively. Depending on flowering synchrony, a higher density of adult trees in a population might not be reflected directly in a higher density of flowering trees. It is argued that density of flowering trees (effective breeding population size), rather than density of adult trees might account for the differences in outcrossing estimates.

The number of flowering trees in the artificial forest is more or less the same as in the seed orchard. However, as shown in Table 1, outcrossing rate in the seed orchard $\left(t_{\mathrm{m}}=0.55\right)$ is lower than in the artificial forest $\left(t_{\mathrm{m}}=0.66\right)$. Effective pollination requires the establishment of some relationship between the plant and its pollinators: the vector must receive sufficient benefit from visiting the flowers to make it continue to act as a pollinator. For honeybees (Apis dorsata and A. indica var. cerrana), the benefit is nectar. The population dynamics of pollinators in a seasonal dipterocarp forest are particular appealing. In these communities, the dipterocarps as well as other species, flower and fruit every few years (Ashton, 1988), and certain groups of trees are serviced by pollinators that migrate from secondary forests during the gregarious flowering (Appanah, 1985). Regionally synchronized mass flowering within dipterocarp species at multiyear intervals is an effective way of promoting widescale development and movement of pollinator population (Ashton, 1988). However, the fate of pollinators during other years is generally unknown. They could subsist on other species that are relatively uncommon but very significant in providing resources to the pollinators at critical periods or, as suggested by Appanah (1985), they might migrate from nearby forest during the gregarious flowering season. This scenario is possible for FRIM's artificial forest as it was established with $D$. aromatica and various dipterocarp and nondipterocarp timber tree species, and is surrounded by primary and secondary forests. A lack of pollinators might be expected in the studied seed orchard as it was established with $D$. aromatica alone and is surrounded by rubber plantations. The high level of correlated mating $\left(r_{\mathrm{p}}=0.43\right)$, and most importantly, the significant level of biparental mating $\left(t_{\mathrm{m}}-t_{\mathrm{s}}=0.12\right)$ observed in seed orchard, may also indicate that the population was genetically substructured, which may suggest further that the seed orchard was established using related seed sources.

In summary, the results indicate that logging activities will increase the proportion of seeds set by selfing. However, if a population is genetically structured to some extent, logging activities may reduce inbreeding caused by consanguineous mating. As further exploitation of tropical forest is unavoidable, forest management systems that can enhance outcrossing events but minimize inbreeding through consanguineous mating, would have a vital impact on sustainable forest management. This is feasible if information on intrapopulation genetic variation is available. The information can be generated using molecular markers or by inferring the mode of pollen and seed dispersal. Establishment of artificial forest and management of regenerated forest should consider the importance of extensive forest stands surrounding the managed areas in providing both pollinators and genes; these latter may buffer the managed areas against reproductive failure or loss of allelic diversity. For seed orchards, the degree of inbreeding displayed by the individual is a critical issue in assessing the genetic quality of the seed crop. The amount of inbreeding is not only dependent upon the genetic propensity towards selfing of an individual, but also on the spatial configuration of the relatives in a plot. Thus, in order to attract pollinators, and at the same time avoid contamination of pollen from individuals outside the plot, it is vital to establish seed orchards in their natural habitat, near or within forest areas consisting of other dipterocarp and nondipterocarp species. In addition, forested areas need to be divided into appropriate planting zones based on available ecological and biological data. Genetically unrelated seedlings can then be planted only in their own planting zones.

\section{Acknowledgements}

The author would like to thank Ang Khoon Cheng for his assistance in the seed collections. Many thanks are also due to Mariam Din, Sharifah Talib and Ghazali Jaafar for their technical help in the laboratory.

\section{References}

ADAMS, W. T. 1992. Gene dispersal within forest tree populations. New Forests, 6, 217-240.

AIZEN, M. A. AND FEINSINGER, P. 1995. Forest fragmentation, pollination, and plant reproduction in a chaco dry forest, Argentina. Ecology, 75, 330-351.

ALlARD, R. W. 1975. The mating system and microevolution. Genetics, 79 (Suppl.), 115-126.

APPANAH, S. 1981. Pollination in Malaysia primary forests. Malay For., 44, 37-42.

APPANAH, S. 1985. General flowering in the climax rain forests of South-east Asia. J. Trop. Ecol., 1, 225-240.

AShton, P. S. 1988. Dipterocarp biology as a window to the understanding of tropical forest structure. Ann. Rev. Ecol. Syst., 19, 347-370. 
ASHTON, G. C. AND BRADEN, A. W. H. 1961. Serum $\alpha$-globulin polymorphism in mice. Aust. J. Biol. Sci., 14, 248-254.

BAWA, K. S. 1990. Plant pollinator interaction in tropical rain forests. Ann. Rev. Ecol. Syst., 21, 399-422.

BAWA, K. S., BUllock, S. H., PERRY, D. R., COVIlle, R. E. AND GRAYUM, M. H. 1985. Reproductive biology of tropical lowland rain forest trees: II. Pollination systems. Am. J. Bot., 72, 346-356.

BROWN, A. H. D. 1989. Genetic characterization of plant mating system. In: Brown, A. H. D., Clegg, M. T., Kahler, A. L. and Weir, B. S. (eds) Plant Population Genetics, Breeding, and Genetic Resources, pp. 145-162. Sinauer Associates, Sunderland, MA.

BROWN, A. H. D. AND ALlARD, R. W. 1970. Estimation of the mating system in open-pollinated maize populations using isozyme polymorphisms. Genetics, 66, 133-145.

BROWN, A. H. D., BURDON, J. J. AND JAROsz, A. M. 1989. Isozyme analysis of plant mating systems. In: Soltis, D. E. and Soltis, P. S. (eds) Isozymes in Plant Biology, pp. 73-86. Dioscorides Press, Portland, OR.

CHAN, H. T. 1981. Reproductive biology of some Malaysian dipterpcarps. III. Breeding systems. Malay For., 44, 28-36.

ClAyton, J. W. AND TRETIAK, D. N. 1972. Amine-citrate buffers for $\mathrm{pH}$ control in starch gel electrophoresis. J. Fish Res. Board Can, 29, 1169-1172.

DAYANANDAN, S., ATTYGALla, D. N. C., ABEYGUNASEKARA, A. W. W. L., GUNATILLEKE, I. A. U. N. AND GUNATILLEKE, C. V. S. 1990. Phenology and floral morphology in relation to pollination of some Sri Lankan dipterocarps. In: Bawa, K. S. and Hadley, M. (eds) Reproductive Ecology of Tropical Forest Plants, pp. 103-133. UNESCO, Paris/ Parthenon Publishing Group, Carnforth, UK.

DOLIGEZ, A. AND JOLY, H. I. 1997. Mating system of Carapa procera (Meliaceae) in the French Guiana tropical forest. Am. J. Bot., 84, 461-470.

FOXworthy, F. W. 1927. Commercial Timber Trees of the Malay Peninsula. Malayan Forest Record no. 3. Forest Research Institute Kepong, Kuala Lumpur.

HALL, P., WALKER, S. AND BAWA, K. S. 1996. Effect of forest fragmentation on genetic diversity and mating system in a tropical tree, Pithecellobium elegans. Conserv. Biol., 10, 757-768.

JAMES, T., VEGA, S., ALDRICH, P. AND HAMRICK, J. L. 1998. Mating system of three tropical dry forest tree species. Biotropica, 30, 587-594.

KITAMURA, K., ABDUL RAHMAN, M. Y., OCHIAI, Y. AND YOSHIMARU, H. 1994. Estimation of the outcrossing rate on Dryobalanops aromatica Gaertn. f. in primary and secondary forest in Brunei, Borneo, Southeast Asia. Pl. Sp. Biol., 9, 37-41.

LEE, S. L., WICKNESWARI, R., MAHANI, M. C. AND ZAKRI, A. H. 2000a. Inheritance of allozyme variants in Shorea leprosula Miq. (Dipterocarpaceae). J. Trop. For. Sci., 12, 124-138.

LEE, S. L., WICKNESWARI, R., MAHANI, M. C. AND ZAKRI, A. H. 2000b. Mating system parameters in a tropical tree species, Shorea leprosula Miq. (Dipterocarpaceae) from Malaysian lowland dipterocarp forest. Biotropica, in press.
LIENGSIRI, C., BOYLE, T. J. B. AND YEH, F. C. 1998. Mating system in Pterocarpus macrocarpus Kurz in Thailand. J. Hered., 89 , 216-221.

MitTON, J. B. 1992. The dynamic mating system of conifers. New Forests, 6, 197-216.

MURAWSKI, D. A. AND BAWA, K. S. 1994. Genetic structure and mating system of Stemonoporus oblongifolius (Dipterocarpaceae) in Sri Lanka. Am. J. Bot., 81, 155-160.

MURAWSKI, D. A., DAYANANDAN, B. AND BAWA, K. S. 1994a. Outcrossing rates of two endemic Shorea species from Sri Lankan tropical rain forests. Biotropica, 26, 23-29.

MURAWSKI, D. A., GUNATILlEKE, I. A. U. N. AND BAWA, K. S. 1994b. The effect of selective logging on inbreeding in Shorea megistophylla (Dipterocarpaceae) from Sri Lanka. Conserv. Biol., 8, 997-1002.

MURAWSKI, D. A. AND HAMRICK, J. L. 1992a. The mating system of Cavanillesia platanifolia under extremes of flowering-tree density: a test of predictions. Biotropica, 24, 99-101.

MURAWSKI, D. A. AND HAMRICK, J. L. 1992b. The mating system and phenology of Ceiba pentandra (Bombacaceae) in Central Panama. Heredity, 83, 401-403.

NASON, J. D., ALDRICH, R. AND HAMRICK, J. L. 1997. Dispersal and the dynamics of genetic structure in fragmented tropical tree populations. In: Laurance, W. F. and Bierregaard, R. O., Jr (eds) Tropical Forest Remnants: Ecology, Management, and Conservation of Fragmented Communities, pp. 304-320. University of Chicago Press, Chicago, IL.

NASON, J. D. AND HAMRICK, J. L. 1997. Reproductive and genetic consequences of forest fragmentation: Two case studies of neotropical canopy trees. J. Hered., 88, 264-276.

RITLAND, K. 1994. Multilocus Mating System Program MLTR. Department of Botany, University of Toronto, Toronto.

RITLAND, K. AND JAIN, S. K. 1981. A model for the estimation of outcrossing rate and gene frequencies based on $n$ independent loci. Heredity, 47, 37-54.

RUDIN, D., MUONA, O. AND YAZDANI, R. 1986. Comparison of the mating system of Pinus sylvestris in natural stands and seed orchards. Hereditas, 104, 15-19.

SAKAI, S., MOMOSE, K., YUMOTO, T., KATO, M. AND INOUE, T. 1999. Beetle pollination of Shorea parvifolia (section Mutica, Dipterocarpaceae) in a general flowering period in Sarawak, Malaysia. Am. J. Bot., 86, 62-69.

SEDGLEY, M. AND GRIFFIN, A. R. 1989. Sexual Reproduction of Tree Crops. Academic Press, London.

SHAw, D. V. AND ALLARD, R. w. 1982. Estimation of outcrossing rates in Douglas-fir using isozyme markers. Theor. Appl. Genet., 62, 113-120.

Symington, C. F. 1943. Forester's Manual of Dipterocarps. Malayan Forest Record no. 16. Forest Research Institute Kepong, Kuala Lumpur. (Reprinted with plates and historical introduction: University of Malaya Press, Kuala Lumpur, 1994).

WYATT-SMith, J. 1964. Manual of Malayan Silviculture for Inland Forests. Malayan Forest Record no. 23. Forest Research Institute Kepong, Kuala Lumpur.

ZHENG, Y. Q. AND ENNOS, R. 1997. Changes in the mating systems of populations of Pinus caribaea Morelet var. caribaea under domestication. Forest Genet., 4, 209-215. 